\title{
A sociologia durkheimiana e a tradição conservadora: \\ elementos para uma revisão crítica
}

Durkheimian sociology and the conservative tradition: elements for a critical review

Na tradição sociológica, o francês Émile Durkheim (1858-1917) é frequentemente alocado no rol dos conservadores. ${ }^{2}$ Muitos são os manuais e as exposições-padrão responsáveis por difundir a imagem de um Durkheim conservador, crítico do individualismo, arauto de uma sociologia "sem sujeito", enfim, um positivista empedernido e compromissado com a manutenção da ordem social. A esse respeito, aliás, podemos avistar críticos bastante diversos, a exemplo do funcionalista Talcott Parsons (2010) e dos marxistas Irvin Zeitlin (1973) e Michael Löwy (2007), para mencionar apenas alguns. Mas, ainda que a pecha conservadora que recai sobre o mestre francês seja predominante, também é possível avistar intérpretes pouco afeitos a essa leitura, tais como Anthony Giddens (1998; 2001; 2005), Ramon Ramos Torre (1999) e Lidia Girola (2005), para os quais a sociologia durkheimiana comporta uma dimensão liberal e até mesmo anticonservadora.

Partindo dessa polêmica, visamos verificar em que medida Durkheim identifica-se com a tradição conservadora e, caso isso fique comprovado, de que tipo de conservadorismo o sociólogo é tributário. Sabe-se que a sociologia durkheimiana, tanto na

\footnotetext{
1 É doutor em Educação pela Faculdade de Educação da Universidade de São Paulo (USP) e professor do Centro Universitário Assunção e do Centro Universitário Sant'Anna. E-mail: <vares@usp.br>.

2 É curioso notar que para alguns representantes do marxismo, sobretudo em seu viés mais ortodoxo, o sociólogo alemão Max Weber (1864-1920) também é considerado um "conservador", pois, assim como Durkheim, em que pesem as diferenças entre eles, sua sociologia serviria de justificativa à ordem social burguesa (Netto, 2011; Löwy, 2006).
} 
primeira quanto na segunda fase de seu desenvolvimento, bebeu em fontes teóricas muitíssimo heterogêneas. Nesse ponto, em especial, cumpre destacar o pensamento social germânico, o pensamento social francês - sobretudo o socialismo saint-simoniano e o positivismo comtiano -, o organicismo britânico e o neokantismo. Todas essas influências, indubitavelmente, ajudaram a emoldurar o pensamento do sociólogo alsaciano. Mas, até que ponto sua teoria sociológica pode ser considerada conservadora? É esse o núcleo problemático sob o qual nos debruçaremos neste artigo.

Para tanto, achamos por bem dividi-lo em quatro partes. $\mathrm{Na}$ primeira delas, visamos definir as linhas gerais do que se denomina "conservadorismo clássico ou moderno". Trata-se, pois, de percorrer, historicamente, o desenvolvimento dessa corrente - sobremaneira na Grã-Bretanha, na França e na Alemanha -, buscando, assim, compreender sua origem, sua estrutura, bem como seus principais pressupostos. Na segunda parte, atentos ao contexto sociopolítico em que suas ideias se desenvolveram, abordaremos as principais influências teóricas de Durkheim com vistas a compreender as bases fundacionais de sua sociologia. Na terceira parte, percorreremos as principais críticas dirigidas a Durkheim, em especial aquelas que, no decorrer da tradição sociológica, atribuíram à sua sociologia uma conotação eminentemente conservadora. Já na quarta e última parte, objetivamos identificar possíveis intersecções entre a sociologia durkheimiana e o pensamento conservador, focando alguns dos temas privilegiados pelo autor em seu programa de pesquisa, para, enfim, posicionarmo-nos em relação à questão que alimenta nossa empresa.

\section{As faces do conservadorismo}

Segundo Leila Escorsim Netto (2011), duas dificuldades preliminares apresentam-se àqueles que desejam compreender mais profundamente o pensamento conservador: respectivamente, o estabelecimento exato de sua gênese histórico-temporal e a determinação de seus traços constitutivos. 
Em relação à primeira delas - a sua origem -, é preciso cercar-se de alguns cuidados, visto que alguns conservadores, a despeito de qualquer referência histórica concreta, tendem a tomar, com frequência, a expressão "conservar" em seu sentido mais lato - ou seja, no sentido de preservar coisas ou ideias que valorizamos e que acreditamos -, como um traço distintivo da "natureza humana". Na visão abrangente e não menos ingênua destes, o conservadorismo não é apenas uma doutrina política, mas a essência da própria vida. Ora, conquanto imbuídos de um discurso pretensamente científico, esses autores pouco ou nada contribuem para elucidar a origem do pensamento conservador, visto adotarem uma perspectiva intemporal e a-histórica, na qual o homem é concebido como um ser estruturalmente dado e o modo de ser conservador como uma "disposição" intrínseca à sua natureza.

Contudo, conforme salienta Andrew Vicente (1995), para além do uso "costumeiro" que se faz do termo "conservadorismo", há outro de caráter mais "técnico", dotado de uma perspectiva bem mais histórica. Isso porque, no que se refere a seu uso político, a maior parte dos estudiosos admite que sua origem data do início do século XIX, após o desfecho da Revolução Francesa. ${ }^{3}$ Ainda assim, alerta o estudioso gaulês, essa segunda maneira de encarar o fenômeno em questão não está, absolutamente, imune a polêmicas, pois é possível avistar pelo menos cinco interpretações a respeito do caráter do conservadorismo: a aristocrática, a pragmática, a situacional, a que assenta na força do hábito e, por fim, a ideológica.

Na primeira delas, o conservadorismo é entendido como uma doutrina de cunho reativo, expressa por uma aristocracia agrária, semifeudal e inconformada com as transformações desencadeadas pela Revolução Francesa.

3 Para a maior parte dos estudiosos, o termo "conservadorismo" aparece pela primeira vez nos Estados Unidos, no início da década de 1800, a partir de alguns membros do Partido Nacional Republicano Americano que autoproclamavam "conservadores". Na França, o termo é inicialmente empregado no jornal de François-René Chateaubriand, Le Conservateur, na década de 1820, representando um discurso politicamente restauracionista e clerical. Já na Grã-Bretanha, desponta no jornal Quarterly Review, em 1830. De modo geral, o termo propaga-se pela Europa a partir da década de 1840, especialmente após as sublevações de 1829-1830 e 1848. 
Em relação à segunda, o conservadorismo é visto, primordialmente, como uma forma de pragmatismo político, ou seja, como uma doutrina sem conteúdo ou princípios definidos, em que tudo que funcione em termos políticos pode ser incorporado ao seu programa.

No tocante à terceira interpretação, a situacional, comumente confundida com a perspectiva pragmática, reflete a postura defensiva consciente das doutrinas políticas institucionalizadas ou de uma ordem particular, voltando-se, nesse sentido, contra esquemas políticos não institucionalizados que transcendam à realidade política do momento. Embora não possua nenhuma substância definida, esse tipo de conservadorismo manifesta-se em situações de desafio às instituições confrontadas por ideias transcendentes, defendendo a ordem existente, seja qual for sua natureza política, contra o caos mudancista ou reformista.

A quarta interpretação, por sua vez, enfoca a noção de disposição, seja sob a alegação de que o sentimento conservador faz parte da própria essência da vida, seja sob a defesa filosófica de uma espécie de "conservadorismo natural". Em suma, para os representantes dessa tendência, o conservadorismo, longe de ser uma ideologia, define-se pelo hábito, pelo familiar, enfim, pela força da experiência.

$\mathrm{Na}$ quinta e última interpretação, o conservadorismo é visto como uma ideologia inequívoca, que não se reduz a nenhuma consideração pragmática ou situacional, nem se define pelo contexto socio-histórico ou classista. Destarte, os conservadores, segundo essa perspectiva, opõem-se a certas ideias revolucionárias baseadas tanto na perfectibilidade da espécie humana quanto na crença no triunfo da razão e no progresso em direção a uma sociedade satisfatória definitiva. Grosso modo, pode-se afirmar que, para seus representantes, o descaso revolucionário em relação à autoridade, aos privilégios, à hierarquia e às tradições soa como um grande absurdo.

Mas as dificuldades em classificar o conservadorismo não param por aqui. Mesmo no interior do pensamento conservador, as 
divergências são enormes. A esse respeito, podemos identificar duas posições antagônicas. A primeira delas defende que há apenas uma única doutrina genuína do conservadorismo, o que invalida a tese acerca dos diversos conservadorismos. A segunda, mais difundida, aponta a existência de diferentes correntes conservadoras, das quais é possível destacar pelo menos três grandes ideologias, a saber: a tradicionalista, a romântica e a liberal. Na visão dos que defendem essa segunda posição, o "conservadorismo tradicionalista" dá maior ênfase aos costumes, às tradições e às convenções sociais e, por isso, a razão teórica é preterida a favor da razão prática. A vida comunitária é vista como um fluxo cumulativo, no qual a mudança, longe de ser resultado do pensamento racional, dá-se naturalmente. As desigualdades entre os homens, bem como a autoridade e a hierarquia, são vistas como produtos naturais, enraizadas no cotidiano da vida comunitária. Quanto ao "conservadorismo romântico", nota-se claramente um tom nostálgico em torno de um passado idealizado de cunho pastoral, rural e anti-industrial. Em geral, os conservadores românticos defendem um modo de vida simples, idílico e religioso, assentado em valores e sentimentos comunais. Já o "conservadorismo liberal" tende a aceitar alguns dos dogmas formais do liberalismo clássico: ênfase no individualismo, na propriedade privada, nos direitos individuais e no Estado mínimo. Isto configura uma dificuldade enorme, pois, em última análise, o conservadorismo pouco ou nada se distancia da tradição liberal.

Como se pode verificar, quando se trata de classificar o conservadorismo, encontra-se tudo, menos clareza. As clivagens e nuances que marcam a noção de conservadorismo tornam o caminho dos estudiosos um tanto quanto nebuloso, não havendo, por isso, um consenso mínimo sobre o assunto, nem mesmo entre os seus representantes.

Embora o modo como as referidas interpretações e definições estejam aqui elencadas possua um viés mais didático do que real, à medida que, entre elas, há uma contínua sobreposição, a utilização usual da noção de conservadorismo identifica-se mais especificamente com sua dimensão ideológica. Visto que a maior parte 
das críticas endereçadas à Durkheim também se refere ao caráter ideológico de sua sociologia, enfatizaremos a origem e o desenvolvimento desta interpretação particular.

\section{A gênese da ideologia conservadora}

Para a maior parte dos especialistas, enquanto ideologia, o conservadorismo seria uma resposta tanto ao protagonismo assumido pelo iluminismo no plano filosófico quanto às conturbações desencadeadas pela Revolução Francesa no plano sociopolítico. Como é sabido, o ideário iluminista não só foi responsável pela erosão do sistema nobiliárquico, rompendo com a estabilidade secular da monarquia, mas também abriu precedentes para a consolidação de uma nova ordem social. Nesse sentido, o pensamento conservador constitui uma expressão cultural particular de um espaço socio-histórico preciso, a saber: o da configuração da sociedade urbano-industrial moderna. Face ao esfacelamento das instituições e dos valores tradicionais, seus representantes insurgem-se contra o racionalismo, a emancipação individual, a dessacralização do mundo, a urbanização, o desenvolvimento científico, os valores democráticos, a constituição do espaço público, enfim, contra a própria modernidade.

Como sublinha o sociólogo americano Robert Nisbet (2003), profundo conhecedor da história da teoria sociológica, enquanto ideologia o conservadorismo desponta, inicialmente, como uma "reação" anti-iluminista e antirrevolucionária. A esse respeito, afirma o autor:

o conservadorismo moderno é, em sua forma filosófica ao menos, filho da Revolução Industrial e da Revolução Francesa; filho imprevisto, não desejado e odiado pelos protagonistas de cada uma delas, porém filho ao fim. O que ambas a revoluções atacaram, foi defendido por homens como Burke, Bonald, Haller e Coleridge, e o que ambas engendraram - na forma de democracia popular, tecnológica, secularismo etc. 
- é o que o conservadorismo atacou (Nisbet, 2003, p. 25, tradução nossa).

Esse excerto é bastante esclarecedor, pois nos possibilita enfrentar a segunda dificuldade anteriormente anunciada, atinente às características do conservadorismo. Conforme deixa entrever, a ideologia conservadora - diferentemente das ideologias "ideacionais" e "ativas" - tem como traço basilar o fato de ser "reativa" e "posicional" (Huntington, 1957). Reativa, pois diz respeito a uma "reação" contra qualquer tipo de ameaça de caráter radical que ponha em risco os fundamentos institucionais da sociedade - como no caso da Revolução Francesa - e posicional, visto tratar-se de uma "tomada de posição" frente a uma necessidade histórica específica, tais como as ideologias que defendem soluções utópicas, apontando para um passado glorioso ou para um futuro incerto.

Disso depreende-se uma distinção fundamental: aquela entre o "reacionarismo", o "utopismo" e o "conservadorismo". Na leitura do cientista político português João Pereira Coutinho (2014), essas ideologias são muito diferentes, pois enquanto as duas primeiras rompem com o presente, seja apontando para uma época de ouro ida, seja apontando para um futuro hipoteticamente superior, esta última mantém-se firmada em instituições e valores supostamente testados do tempo - entenda-se testadas pela própria história. Em outras palavras, o conservadorismo configura-se como uma ideologia politicamente "prudente" quando comparada às ideologias concorrentes (Kirk, 2013).

Não por acaso, para a maior parte dos especialistas, o político e pensador anglo-irlandês Edmund Burke (1729-1797) desponta como o principal representante da ideologia conservadora moderna. Afinal, ele não só testemunhou todo o alvoroço provocado pela Revolução Francesa, como também deu a sua visão dos fatos. Suas Reflexões sobre a Revolução na França (obra originalmente 
publicada em 1790) tornaram-se referência para o pensamento conservador moderno e contemporâneo. ${ }^{4}$

\section{Burke e as bases do conservadorismo liberal inglês}

Embora falte às formulações de Burke uma maior sistematização - sua obra consiste em uma série de cartas, discursos parlamentares e panfletos circunstanciais -, é possível extrair as linhas-mestras de seu pensamento político quando se considera o conteúdo exposto em suas Reflexões. Como primeiro grande crítico da Revolução Francesa, Burke adota um tom severo em relação aos princípios abstratos que a nortearam. O autor não aceita as posições sustentadas pelos revolucionários franceses, consideradas demasiadamente genéricas e abstratas - noções como a de liberdade, igualdade e fraternidade soam, para ele, como utópicas (Escorsim Neto, 2011).

Ainda assim, suas críticas às ideias revolucionárias, bem como as posições fundamentais que defendia, não deixam de se assentar em fundamentos metafísicos, uma vez que o autor admite a existência de uma realidade superior subjacente ao fluxo dos fatos. O papel proeminente da religião em seu esquema explicativo faz com que Burke considere Estado e sociedade como partes da ordem natural do universo. Segundo o autor, tanto o homem quanto a sociedade são criações divinas e, assim, ambos estariam submetidos a leis eternas, responsáveis por regular não só a dominação do homem pelo homem, mas, igualmente, os direitos e as obrigações de governantes e governados. Destarte, a noção de igualdade não passa de uma "monstruosa ficção" que só serve para subverter a paz social, tornando mais amarga a desigualdade real estabelecida pela ordem civil, que não pode ser definitivamente eliminada. Aliás, na ótica de Burke, esse foi o grande equívoco dos revolucionários franceses: apostar que a igualdade constitui um direito universal (Kinzo, 2006).

Decerto, a noção de natureza humana, sob a qual se assenta todo o edifício argumentativo do autor, carece de clareza. Dela

4 Em relação à influência de Burke sobre as correntes conservadoras modernas e contemporâneas, consultar os trabalhos de Robert Nisbet (1995) e João Pereira Coutinho (2014). 
fazem parte tanto considerações teológicas - por exemplo, a dependência humana em relação à incompreensível Providência Divina - quanto referências empíricas - o conhecimento que os homens têm da natureza em função da experiência. Isto, entretanto, não fragiliza o fulcro de sua argumentação: a existência de uma realidade que não depende dos indivíduos e que só pode ser apreendida com referência à tradição lentamente forjada por nossos ancestrais. Em oposição ao jusnaturalismo rousseaísta, Burke defendia que o contrato sobre o qual se funda uma organização social sólida e equilibrada instaurou-se progressivamente, no curso do qual se revelaram os benefícios do bom senso, da virtude e da liberdade, e não por meio da deliberação arbitrária de um indivíduo. Defensor da ordem, da hierarquia, dos direitos herdados e da continuidade histórica, mas também da economia de mercado, da tolerância religiosa e dos princípios liberais que caracterizavam a Constituição Inglesa, o Whig Burke, que provavelmente nunca se considerou um conservador em matéria de política, passou à história não só como o maior crítico da Revolução Francesa - acontecimento que, segundo ele, diferia das demais revoluções por seu caráter universalista -, mas, também, como a principal fonte de inspiração para aqueles que, durante o terço de século que se seguiu à sua morte, assumiram-se como conservadores. Por tudo isso, Burke pode ser visto como um "conservador liberal" (Vicente, 1995; Coutinho, 2014).

\section{De Maistre, Bonald e Chateaubriand: o conservadorismo romântico francês}

Se, como afirma Nisbet (2003), o conservadorismo moderno é filho imprevisto e indesejado da Revolução Industrial e da Revolução Francesa, é de se esperar que as críticas conservadoras se dirigissem às reivindicações e às transformações desencadeadas por ambas. Burke foi o iniciador desse processo, porém, na viragem do século XVIII para o século XIX, outros autores também se insurgiram contra as ideias iluministas. No caso da França, pode-se apontar pelo menos três grandes expoentes do pensamento conservador, 
são eles: Joseph de Maistre (1753-1821), Louis de Bonald (17541840) e François-René de Chateaubriand (1758-1848).

Comumente encarados como pensadores estranhos, com certos traços góticos e românticos, esses três autores empreenderam um ataque incisivo aos valores centrais do iluminismo. Viam com descrença as transformações culturais, políticas e econômicas processadas no decorrer da modernidade, pois, grosso modo, essas mudanças tinham como signo um exacerbado sentimento individualista, o que constituía uma ameaça às tradições e à ordem social instituída. Mas, no caso específico desses filósofos franceses, pode-se observar certa nostalgia em relação ao Ancien Régime, que havia sido derrotado pela revolução. Aliás, cumpre assinalar, esse sentimento passadista, nostálgico, não ocorreu exclusivamente na França. Durante o século XIX, explica Nisbet (2003), presencia-se uma oposição à modernidade na forma de um recrudescimento em direção ao mundo medieval. Em outras palavras, a Idade Média tornou-se objeto de atenção de um grande número de pensadores nos mais variados países, forçando uma comparação com o estilo de vida que emergia com a modernidade.

Em terras francesas, porém, esse espírito medievo recebeu grande atenção por parte desses pensadores, servindo como ponto de partida para as suas investigações históricas, políticas e culturais. Tudo isso com vistas a demonstrar o declínio representado pelo advento moderno. Longe de aceitarem o progresso de uma sociedade cada vez mais alicerçada na urbanização, na industrialização e na democratização dos processos políticos e decisórios, esses "profetas do passado" não tardaram em apontar, por meio de suas reflexões, a corrupção da família, da religião e da ordem como efeitos perniciosos de um processo iniciado durante o Renascimento e a Reforma Protestante e que atingiu o seu cume com a famigerada Revolução Francesa, enfim, a falência do que consideravam uma sociedade justa, pacífica e verdadeiramente livre.

Maistre, por exemplo, ergueu-se contra a revolução, sobretudo porque esta atentava contra as instituições tradicionais. Acreditava que o modelo monárquico era intrínseco à estrutura nativa da 
sociedade francesa. $\mathrm{Na}$ contramão das posições racionalistas, o filósofo alegava que todas as questões sobre a natureza da sociedade deveriam ser solucionadas pela história, e não pelos homens.

Bonald, provavelmente o mais erudito e profundo filósofo entre os conservadores franceses, dedicou-se ao tema da autoridade política e religiosa, opondo-se com energia à filosofia do direito natural e do estado natural.

Chateaubriand, por seu turno, comprazia-se, fingindo defender alguns iluministas como forma de lançá-los uns contra os outros. Voltaire, cujos brilhantes ataques ao Cristianismo também atingiam os conservadores, foi sem dúvida o seu alvo preferido.

Certamente por isso, observa Nisbet (1986; 2003), a geração de Comte e de Le Play viu-se tentada a dar continuidade às críticas iniciadas pelos conservadores franceses na virada do século. ${ }^{5}$

\section{Möser, Müller, Hegel e o conservadorismo tradicionalista alemão}

Na Alemanha, os impactos da Revolução Francesa também se fizeram sentir, e, em virtude disso, verifica-se a presença de um discurso conservador bem delineado. Justus Möser (1720-1794), que antecedeu Burke, lança mão de vários princípios inerentes ao modo de pensar conservador. Em seus Discursos Patrióticos (17741786), coleção de ensaios publicados em vários volumes no decorrer da segunda metade do século XVIII, encontram-se os princípios básicos do pensamento conservador que, mais tarde, ressoarão na obra de Burke. Nota-se, por um lado, uma crítica contundente ao racionalismo e ao individualismo, além de uma oposição ferrenha à fé no direito racional-prescritivo e, por outro, uma defesa não menos enérgica das tradições. Sobre os costumes e as instituições de um povo, aliás, o autor é bastante enfático: estes resultam de uma evolução histórica, de tal modo que nenhum legislador, solitária e arbitrariamente, pode apreender e converter em leis as necessidades coletivamente engendradas ao longo do tempo (Vicente, 1995).

5 Em muitas ocasiões, Comte e Le Play referem-se elogiosamente aos conservadores franceses, atestando, por assim dizer, essa influência sob seus respectivos sistemas de pensamento (Nisbet, 2003). 
Adam Müller (1779-1829) conhecia a obra de Burke muito bem, nutrindo grande admiração pelos princípios fundamentais de sua filosofia. Nesse sentido, sua concepção de Estado, bem como sua visão acerca da economia, ambas contidas na obra Elementos do Estadismo (1810), é similar à concepção e à visão do autor irlandês.

Georg Wilhelm Friedrich Hegel (1770-1831) é, de longe, a força mais influente do conservadorismo alemão. Durante a juventude, sua inclinação liberal-radical justifica seu entusiasmo pela Revolução Francesa. No decorrer de sua trajetória, entretanto, aderiu fortemente ao tradicionalismo. Seus Princípios da Filosofia do Direito (1820), publicados quando ainda era professor da Universidade de Berlim, mantêm grande parte da visão que Burke ou Bonald mantinham em relação à sociedade. Paradoxalmente, sua filosofia - em especial o seu método dialético - prestou grandes contribuições tanto ao pensamento conservador quanto ao pensamento radical. ${ }^{6}$

Todos eles, sem exceção, contribuíram no sentido de estabelecer as bases do conservadorismo alemão, exercendo decisiva influência sobre as gerações seguintes, como no caso dos historicistas conservadores alemães, ainda nas primeiras décadas do século XIX. ${ }^{7}$

\section{Os traços fundamentais do pensamento conservador}

Isso posto, temos condições de traçar as linhas gerais da mentalidade conservadora. De modo geral, pode-se afirmar que, em termos sociais, morais e políticos, os conservadores não aceitam transformações abruptas ou repentinas. Qualquer tipo de ação que atente contra o establishment ou gere instabilidade é imediatamente combatida. Arraigados às tradições (consideradas pedagógicas e

\footnotetext{
6 Karl Marx, indubitavelmente, exemplifica bem de que modo o pensamento hegeliano serviu de base para o materialismo dialético. A esse respeito, ver Anthony Giddens (2001; 2005).

7 Michael Löwy (2006) argumenta que a corrente historicista alemã flertou, em sua origem, com o conservadorismo, exaltando as instituições e os valores tradicionais diante das transformações políticas conduzidas por Otto von Bismark a partir de 1870. Mas, apesar do caráter conservador, a corrente historicista, segundo o autor, teve um papel fundamental tanto para a historiografia quanto para as ciências sociais, pois, em um segundo momento, mais precisamente no último decênio do século XIX, temas como o da objetividade científica e da verdade universal são colocados em xeque, dando forma ao que denomina de "historicismo relativista", do qual o historiador alemão Gustav Droysen e o sociólogo Wilhelm Dilthey foram os principais representantes.
} 
formativas), seus representantes entendem que as mudanças devem ser tuteladas pelo passado e, por isso, são poucos afeitos aos riscos inerentes tanto às soluções utópicas quanto às reacionárias. ${ }^{8}$ Ainda que admitam mudanças, estas são sempre calculadas, adquirindo uma roupagem processual, mas nunca radical. Assim, na perspectiva conservadora, a crença de que é possível modificar a realidade por meio da razão não passa de uma posição arrogante e quimérica, visto que, entre a idealização e a concretização, repousa o imponderável. Outro ponto fundamental para a ideologia conservadora diz respeito à suposta perfectibilidade do intelecto humano. Em geral, os conservadores rechaçam esse tipo de argumento, pois consideram que, mediante a complexidade dos fenômenos sociais, a razão humana mostra-se precária e, por conseguinte, incapaz de transformar a realidade a seu bel prazer. Ademais, noções como as de democracia e liberdade são completamente estranhas à perspectiva conservadora. A defesa de uma soberania popular - una, indivisível e inalienável, como queriam os iluministas franceses - acarreta dois sérios problemas para os conservadores clássicos, quais sejam: a laicização do universo político e a fundamentação da liberdade na autonomia individual. Em outros termos, a separação entre Estado e Igreja, bem como a centralização das decisões políticas na vontade geral, resultaria na pulverização da unidade social, pois, à medida que as paixões humanas são insaciáveis, a liberdade irrestrita eliminaria a hierarquia e a ordem, pressupostos sem os quais os impulsos egoístas não podem ser limitados. Vê-se claramente que o pensamento conservador, anverso do pensamento iluminista, constituiu-se em resposta aos efeitos deletérios da modernidade, afinal, quase todos os seus representantes integravam o complexo católico-monárquico-aristocrático, sofrendo, direta ou indiretamente, os impactos da legislação revolucionária sobre a propriedade e a estrutura de poder, especialmente na França.

8 Isso explica porque para autores como Leila Escorsim Netto (2011) e José Paulo Netto (2011) há uma forte identificação entre a ideologia conservadora e a perspectiva evolucionista de sociedade. Em geral, a ideia segundo a qual as mudanças só podem ocorrer em termos graduais, sem rupturas radicais, típica do pensamento conservador, pressupõe uma visão evolucionária dos processos sociais. 


\section{A sociologia durkheimiana e suas influências}

Para uma parte da literatura especializada, Durkheim não passa de um mero "discípulo" de Saint-Simon e Comte, responsável por dar continuidade à filosofia positivista destes. Não por acaso, observa Ivan Domingues (2004), a maioria das exposições referenciais e dos textos didáticos dirigidos a estudantes secundários e universitários ainda hoje tende a caricaturar a imagem do mestre francês, apresentando-o como uma espécie de "positivistão", um positivista "turrão", um “campeão da ciência”. Essa leitura, entretanto, está longe de ser correta, sobretudo quando se considera os aspectos substantivos de sua teoria sociológica. Se, entre eles, existem similaridades, existem, também, muitas diferenças. Como veremos, as influências durkheimianas vão muito além do positivismo saint-simoniano e comtiano. Aliás, o objetivo desta seção é justamente identificar as fontes teóricas com as quais Durkheim dialogou e que serviram de base para a edificação de sua teoria sociológica.

\section{O positivismo francês: influências e diferenças}

Steven Lukes (1984), naquela que é considerada a mais importante biografia sobre o mestre francês, afirma que entre os anos de 1878 e 1882, ainda enquanto estudante de filosofia na École Normale Supérieure, David Émile Durkheim deu os primeiros indícios de sua verdadeira vocação ao dedicar-se com afinco ao estudo dos fenômenos sociais. De fato, esse foi um período extremamente prolífero para o então jovem estudante universitário. O modo sério, rigoroso e maduro com que encarava os estudos, reflexo da austera formação familiar, somado à sua enorme capacidade intelectual, confluiu para que ele se lançasse em direção à filosofia social, rompendo definitivamente com a tradição rabínica que, há muitas gerações, confundia-se com a trajetória de sua família. ${ }^{9}$ Ao ingressar na École Normale Supérieure, Durkheim não imaginava que estava para se

9 Émile Durkheim era oriundo de uma família judia, há décadas radicada em terras francesas. Seu pai, Moisés Durkheim, dando continuidade a uma longa tradição familiar, era o líder rabínico de sua comunidade, legado esse que, como primogênito, David Émile Durkheim estava destinado a preservar. 
tornar um ícone, talvez o maior, da sociologia francesa. A estimulante atmosfera intelectual que o cercava foi certamente decisiva para o direcionamento de seus interesses acadêmicos. Professores renomados, como os filósofos Émile Boutroux e Charles Renouvier e o historiador Fustel de Coulanges, muito contribuíram para isto. Os dois primeiros ajudaram Durkheim a formar suas convicções políticas, levando-o a abraçar a causa republicana. Já com este último, aprendeu a dirigir seu olhar para os fenômenos culturais, adotando, a exemplo do mestre, uma perspectiva histórica em suas análises. Essas influências iniciais foram, nesse sentido, decisivas para o seu projeto acerca da criação de uma ciência dedicada aos fenômenos sociais. A tentativa em si não era nova. Tanto Saint-Simon quanto Comte tinham proposto algo muito parecido. Porém, diferentemente destes, Durkheim dedicou a sua vida à institucionalização da nova ciência, comprando brigas e procurando impor sua visão sobre as visões concorrentes. Mas em que medida esses precursores teriam influenciado Durkheim?

Para Irving Zeitlin (1973), existem mais similaridades entre Saint-Simon e Durkheim do que entre este e Comte. Isso não só pelo fato de as ideias comtianas serem, sumariamente, o desenvolvimento lógico das contribuições de Saint-Simon, a quem Comte secretariou por alguns anos, mas devido ao próprio Durkheim, em um estudo inconcluso sobre o fenômeno do socialismo, admitir a influência decisiva desse filósofo social para a formulação de sua sociologia. Decerto, a importância de Saint-Simon é significativa. Não é demais destacar o otimismo que os dois pensadores nutrem em relação à sociedade industrial, urbana e científica. Um e outro adotam um escopo francamente evolucionário segundo o qual a sociedade é uma comunidade de valores que passou de um estado pré-industrial para um estado industrial. Ambos os sistemas sociológicos atribuem um papel integrador aos sentimentos morais, inclusive no que se refere às sociedades complexas, caracterizadas por uma acentuada divisão do trabalho. Ademais, na esteira do que propugnava Saint-Simon, Durkheim concebe a sociedade como 
uma realidade sui generis, moralmente superior quando comparada ao indivíduo isolado.

No que se refere a Comte, indubitavelmente no início de sua trajetória intelectual, Durkheim sentiu-se atraído por seu "positivismo" entendido em um duplo sentido: a) como o estudo dos fenômenos sociais pelo mesmo método utilizado pelas ciências naturais; b) como oposição ao "negativismo" dos iluministas e seus herdeiros, cujos interesses resumiam-se à dissolução das instituições. Basta lembrar que a primeira versão de sua tese doutoral, Da Divisão do Trabalho Social, continha uma especial deferência à tentativa do filósofo de Montpellier fixar as bases de uma "física social"."10 Durkheim aproveitou largamente as ideias gerais de Comte sobre a importância da indução na investigação científica e sobre o papel auxiliar das hipóteses, além de certas noções bem definidas de sua investigação sociológica - em particular, a de que a sociologia pode praticar em seu terreno de pesquisa a "experimentação indireta" e a "observação pura". Ademais, também atribuiu fundamental relevância ao método comparativo e à análise causal, tanto em seu espírito quanto em seus fundamentos. Como Comte, Durkheim auferia à sociologia um caráter reformista, um instrumento de intervenção e transformação da realidade, além de sustentar que os fenômenos sociais podiam ser analisados em termos objetivos, desde que o sociólogo mantivesse certo distanciamento - uma postura imparcial - frente a seu objeto.

Mas, não obstante as aproximações entre Durkheim, Saint-Simon e Comte, as diferenças entre eles são igualmente claras.

Durkheim, por exemplo, jamais partilhou da posição de Saint-Simon a respeito das formas de autoridade adequadas ao Estado industrial moderno. Ainda que admitisse que a ordem social emergente fundava-se na complexa divisão funcional imposta pelo avanço da indústria, não a encarava em termos eminentemente econômicos. Para ele, a autoridade atinente ao Estado não podia

10 Aliás, esse foi um ponto problemático durante a defesa pública de seu doutorado, já que a banca examinadora, formada essencialmente por professores identificados ao espiritualismo francês, exigiu a exclusão dessa deferência para a aprovação da tese (Lukes, 1984). 
ser confinada a uma simples “administração de coisas", restringindo-se à regulação da produção. Como deixa claro em sua tese doutoral, "nem tudo é contratual no contrato". Em outras palavras, as transformações econômicas, por si mesmas, mostram-se incapazes de solucionar a crise moderna, entendida pelo autor como uma crise de ordem moral. As relações econômicas só são possíveis mediante certas condições de sociabilidade previamente admitidas, isto é, um sistema social regido por normas e valores que comporte modelos de ações diferenciadas. Contrariamente ao que propunha Saint-Simon, Durkheim não via uma descontinuidade absoluta entre as sociedades tradicionais e as sociedades urbano-industriais, já que estas estão desprovidas de valores e normas. Considerando que para o mestre francês os desejos individuais são insaciáveis, o egoísmo radical é um risco eminente. Por isso, qualquer limitação moral e jurídica à busca desenfreada dos indivíduos pela realização de seus interesses deve ser tutelada pelo Estado, pois, do contrário, os interesses coletivos ficarão à mercê dos apetites individuais. Disso não decorre que a moralidade inerente às sociedades homogêneas, cuja principal característica é a forte presença de uma "consciência coletiva", seja adequada às sociedades heterogêneas. Como ressaltou em certa ocasião, "os velhos deuses estão mortos" e não há como exumá-los. Por sua complexidade, as sociedades altamente diferenciadas necessitam de uma nova forma de vida moral. Em um artigo escrito por ocasião do Caso Dreyfus, intitulado $O$ Individualismo $e$ os Intelectuais, Durkheim esclarece a qual tipo de moralidade está se referindo: o "individualismo moral" ou "culto ao indivíduo". Trata-se, pois, de um conjunto de valores cujo fulcro é o próprio indivíduo. Porém, a centralidade do indivíduo, aqui, nada tem a ver com aquela requerida pelos representantes do utilitarismo ou do pensamento econômico clássico. Como se apressa em explicar, o individualismo moral é resultado de um longo processo histórico e social. Por isso, a base desse tipo de moralidade não é o homem isolado, mas o homem em abstrato - preconizado pela Declaração dos Direitos do Homem e do Cidadão. 
Já em relação a Comte, é inegável que este bebeu das fontes dos apologistas católicos conservadores, influência manifesta em seu Sistema de Política Positiva. Entretanto, como observa Giddens (2001), foi sua obra Filosofia Positiva, e não aquela, que exerceu influência decisiva sobre Durkheim. Assim, ao elaborar suas ideias substantivas acerca do desenvolvimento da sociedade moderna, Durkheim debruçou-se com maior afinco sobre a versão hierocrática emergente proposta por Saint-Simon do que a formulada por Comte em seu Sistema de Política Positiva. Além do mais, se ambos encaravam a sociedade como resultado de um longo processo evolutivo, Durkheim jamais adotou uma visão teleológica da história, dando, nesse sentido, maior atenção ao imponderável. Em outras palavras, ele rejeitava a filosofia da história comtiana, segundo a qual a realização máxima da verdade dar-se-ia por meio de etapas progressivas, considerando-a um punhado de princípios metafísicos a priori. Quanto ao otimismo que nutria em relação à modernidade, a análise durkheimiana não se apresentava em termos valorativos, isto é, não opunha o modelo social moderno que Comte considerava superior - ao modelo social tradicional. Em termos metodológicos, as diferenças são ainda mais gritantes, pois, em última instância, o método durkheimiano procurou superar, de forma coerente com os princípios da investigação indutiva, a circularidade racionalista do encadeamento entre teoria e observação inerente à concepção comtiana. ${ }^{11}$

\section{A influência do pensamento social alemão}

Nos meses em que viveu na Alemanha, naquela que foi a sua única experiência internacional, Durkheim tomou contato com a obra de um grupo de pensadores germânicos, formado quase que exclusivamente por economistas e juristas. Esse intercâmbio

11 Conforme explicita Fernandes, a circularidade comtiana consistia em exigir uma teoria para observar os fatos, quando a própria teoria deveria resultar da observação dos fatos. Mesmo admitindo que uma observação benfeita deva muito a uma teoria já constituída, para Durkheim esta não é o produto necessário dos conhecimentos previamente obtidos, mas, ao contrário, representa a via inevitável para alcançá-los. Destarte, os sociólogos se beneficiarão da teoria à medida que a investigação sociológica progredir (Fernandes, 1980, p. 72). 
intelectual, se não foi decisivo para o pensamento do sociólogo francês, ajudou-o pelo menos a amadurecer algumas ideias cultivadas desde o tempo da universidade. Autores como Schäffle, Lilienfeld, Schmoller, Wagner, Jhering, Wundt e Post chamam a atenção do jovem estudante francês, a ponto de dedicar-lhes, pouco depois de retornar ao seu país de origem, algumas análises críticas. Destas, duas merecem destaque: a resenha dedicada à primeira parte de um dos trabalhos de Schäffle, Bau aud Leden Socialen Korpers, e o longo artigo intitulado A Ciência Positiva na Moral Alemã, no qual analisa o esforço seminal para a criação de uma ciência moral, levado a cabo por alguns desses autores. Ambos repercutiram positivamente e oportunizaram a Durkheim, por intermédio do republicano Louis Liard (na época diretor da educação superior), a cátedra de "Ciência Social e Educação" na Universidade de Bordeaux. ${ }^{12}$

Genericamente, pode-se afirmar que Durkheim endossa a maior parte das propostas desses pensadores. Em que pesem as diferenças metodológicas, todos eles apontam para um mesmo princípio, a saber: aquele segundo o qual a sociedade constitui uma unidade com características específicas, que não se reduzem à soma das suas partes. ${ }^{13}$ Esta não é um mero agregado de indivíduos, mas, antes, um ser cuja existência supera, tanto lógica quanto ontologicamente, a existência de seus membros. Isso porque os ideais e os sentimentos que constituem a herança cultural de uma sociedade são impessoais, à medida que se desenvolvem socialmente, e não a partir de indivíduos específicos. O referido enfoque, claramente sociocêntrico, não possui, todavia, qualquer implicação metafísica. Trata-se apenas de um esforço no sentido de mostrar a consciência coletiva como um composto que apresenta características próprias, portanto independentes das consciências individuais por meio das quais se manifesta.

12 O primeiro desses artigos foi publicado em 1885 e o segundo em 1887, ambos na Revue Philosophique. Este último, inclusive, ganhou uma tradução em português, recebendo um novo título, a saber: Ética e Sociologia da Moral.

13 Como demonstra Giddens (2005), Durkheim estava familiarizado com esse axioma desde os tempos de estudante. Basta lembrar que o primado da consciência coletiva sobre as consciências individuais já aparecia nos trabalhos de pensadores franceses como Saint-Simon, Comte e Renouvier. 
Outro ponto com o qual Durkheim mostrava-se de pleno acordo diz respeito à possibilidade de uma ciência moral. Segundo o sociólogo francês, uma das contribuições mais importantes legadas pelo pensamento social alemão está na recusa tanto às concepções éticas kantianas - segundo as quais os valores morais podem ser deduzidos de princípios abstratos - quanto às concepções éticas utilitaristas para as quais a moralidade deriva, espontaneamente, das relações econômicas. Isso porque, para seus representantes, as regras e as ações morais são propriedades da organização social, modeladas pelas necessidades coletivas, sendo, por isso, possível estudá-las cientificamente. Por seu caráter empírico, tanto para os representantes do pensamento social francês quanto para Durkheim, os fatos morais podem ser observados, classificados, interpretados e descritos como quaisquer outros fenômenos.

Como é possível constatar, esses princípios já se faziam presentes entre os pensadores sociais franceses da primeira metade do século XIX, porém, diferentemente destes, os pensadores germânicos conseguiram alcançar um importante grau de institucionalização, tornando-os hegemônicos do ponto de vista acadêmico. Com efeito, talvez não seja equivocado afirmar que a passagem de Durkheim pela Alemanha contribuiu no sentido de consolidar algumas de suas impressões seminais acerca do primado da realidade social que, pouco depois, revelou-se uma das marcas distintivas de sua sociologia.

\section{A influência da filosofia neokantiana}

Entre os estudiosos de Durkheim, é possível avistar uma divisão em relação ao desenvolvimento de seu pensamento. Para uma parte dos intérpretes, a sociologia durkheimiana desloca-se de uma fase materialista, caracterizada por uma análise de cunho morfológico, para uma fase idealista, marcada pela prevalência de temas e subtemas típicos do universo cultural e moral. Outros intérpretes, entretanto, apressam-se em negar essa hipótese, apontando para uma continuidade entre as obras iniciais e finais do autor. Mas, a despeito desse embate, a interpretação predominante na tradição 
sociológica deu grande ênfase ao período relativo a seus primeiros trabalhos, consagrando a interpretação segundo a qual a sociologia durkheimiana desenvolveu-se na direção da filosofia comtiana.

Porém, o positivismo está longe de ser a sua única fonte teórica. Isso porque, ao longo de sua formação, Durkheim interagiu com outras correntes de pensamento, tão ou mais importantes do que aquela. Esse é o caso, por exemplo, da filosofia neokantiana. Como observa Edward Tiryakian (1980), durante o período em que permaneceu na École, Durkheim sofreu grande influência do pensamento neokantiano, por meio de intelectuais como Boutroux e Renouvier. A filosofia kantiana, que havia penetrado em território francês ainda nas primeiras décadas daquele século, acabou revitalizada e difundida, em especial entre os republicanos, tendo como principal veículo os liceus (equivalentes às escolas secundárias) e as

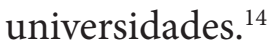

A razão dessa afinidade é, até certo ponto, fácil de explicar. Basta lembrar que, em sua Crítica da Razão Pura, Kant empenhou-se em salvar a certeza do conhecimento do ceticismo devastador de David Hume. Sua tentativa para restabelecer os limites da certeza absoluta sem recorrer diretamente a Deus, lançando as bases de uma moralidade racional, ia ao encontro do desejo republicano de uma moral laica. Em um país como a França, em que a ascendência da ciência - seja em sua vertente evolucionista, seja na organicista - e da visão do homem enquanto ator motivado pelo interesse econômico havia, também, abalado a confiança na estabilidade do mundo, a proposta kantiana não podia ser mais adequada. Afinal, o filósofo de Königsberg opunha-se ao individualismo e ao relativismo sem

14 Sobre a difusão do pensamento neokantiano entre os republicanos franceses, vale destacar o romance de Maurice Barrès, Les Déracinés, publicado em 1897. Trata-se do primeiro volume de uma trilogia intitulada I'Energie Nationale. Contemporâneo de Durkheim, Barrès experimenta a mesma educação secundária no Liceu de Nancy, província de Lorena, baseada em pressupostos laicos e republicanos. O livro retrata um grupo de estudantes secundários que, no último ano, tem como professor de filosofia o "kantiano entusiasta"Bouteiller. Cumpre recordar que o neokantismo adquire grande prestígio na Terceira República Francesa, principalmente nos meios universitários parisienses, embora tenha extrapolado o mundo acadêmico e se convertido em uma espécie de moral secular. A releitura de Kant, pensador alemão do século XVIII, e a introdução de elementos cientistas e racionalistas fazem do neokantismo, até certo ponto, uma forma eficaz de se opor à moral católica tradicional dentro dos moldes requeridos pelo republicanismo francês. 
adotar um tom reacionário, isto é, sem apelar às instituições do passado ou às explicações metafísicas tradicionais, proporcionando um enquadramento ideal em relação aos dilemas de cunho epistemológico e moral.

O modo como Durkheim retraduz as ideias kantianas, portanto, merece nossa atenção. Isso porque o mestre francês procura adaptá-las ao método sociológico, o que, segundo a maioria dos estudiosos, configurou uma espécie de "sociologização do kantismo". Sabe-se que entre os méritos de Kant está o de ter superado a velha querela entre empirismo e racionalismo, por meio de um racionalismo crítico. Durkheim conhecia razoavelmente bem as propostas kantianas, tão marteladas durante sua formação básica e universitária. A tese kantista de que todo o conhecimento resulta de uma síntese a priori congrega dois princípios fundamentais, a saber: a) o entendimento possui uma base empírica, limitando-se à experiência fenomênica, uma vez que não pode atingir as coisas em si mesmas, suas essências; b) a relação de conhecimento caracteriza-se pela subordinação do objeto ao sujeito cognoscente, que ordena, dentro de certas noções a priori (categorias e formas), os dados da experiência sensível. Em suma, conhecer é produzir juízos, relacionando dados, noções, coisas e ideias por meio de sínteses. Pois bem: Durkheim recusa esse último ponto. Conquanto admita que o conhecimento se dê em termos de relação entre sujeito e objeto, não endossa o postulado segundo o qual as diversas categorias do entendimento são inatas, naturalmente anteriores à experiência. Afinal, isso corresponderia a aceitar a precedência lógica do indivíduo sobre a sociedade, impedindo, não obstante, o estabelecimento da sociologia. Para ele, embora os aparatos categoriais e formais sejam anteriores a cada ato cognitivo, não o são em relação à experiência em geral, visto constituírem-se no interior dela. Noções como as de tempo e espaço - para mencionarmos as mais emblemáticas - são construções coletivas, e não individuais. Desse modo, Durkheim lança as bases de uma sociologia do conhecimento, que, intersectada por seus estudos sobre religião, abre espaço para uma abordagem sociológica dos fenômenos morais consoante aos ideais 
republicanos com os quais comungava. Na leitura do sociólogo, a fonte transcendental da qual deriva a ação moral é a sociedade, cuja existência é anterior e posterior à de seus membros.

Há, todavia, um segundo ponto de aproximação entre os dois pensadores: o que se refere aos atributos da regra moral. Kant afirmara que toda regra moral é inevitável para o indivíduo, à medida que se lhe impõe. Durkheim abraça a posição kantiana acerca do "dever", porém, incrementa outro atributo, a saber: a "desejabilidade". Segundo o sociólogo francês, as regras morais são, a um só tempo, obrigatórias e desejáveis, o que faz do fenômeno moral uma especificidade em relação a outras regras de conduta. Com isso, Durkheim suaviza o caráter coercitivo da moralidade, bem como abre espaço para se pensar a adesão à moral como uma possibilidade para o indivíduo transcender os limites de sua animalidade, alcançando uma segunda natureza, a social.

Por último, é ainda possível avistar a influência de Kant em relação à tentativa durkheimiana de fundar uma ciência moral. Não porque o filósofo alemão tenha preconizado qualquer empreendimento dessa natureza, mas pelo fato de atribuir um sentido prático à ação moral. Não é demais recordar que Kant, em consonância com o asceticismo protestante, aborda em sua filosofia temas como a "autonomia da vontade", o "imperativo categórico" e o primado do "dever", conciliando motivação individual e orientação coletiva, elementos fundamentais para a formulação de uma moralidade laica. Essa relação entre ciência e moral, e mais genericamente entre conhecimento e valores, é retomada por Durkheim, que aproxima os juízos de fato e os juízos de valor, deduzindo as duas razões kantianas (a especulativa e a prática) de uma única fonte - a sociedade -, à medida que ambos supõem ideais (valores e conceitos). Esse tour de force possibilitou ao sociológico francês não só superar a aparente antinomia entre ciência e moral, mas também reivindicar para a sociologia o estatuto de instrumento explicativo e transformador da ética, colocando-a no centro da reconstrução social e moral da sociedade francesa. 


\section{Sob fogo cruzado: as críticas à sociologia durkheimiana}

Grosso modo, os críticos que inscrevem Durkheim no interior da tradição conservadora apontam algumas características - tais como a percepção evolucionária da história, o naturalismo metodológico, o cientificismo, o organicismo e seus efeitos -, que supostamente definem a sua sociologia. Nesta seção, objetiva-se contemplar as críticas mais contundentes ao pensamento durkheimiano. Para fins didáticos, e com vistas a detectar o cerne dessas interpretações, decidimos separá-las. Também optamos por não nos posicionarmos, pelo menos agora, em relação ao conteúdo de cada uma delas, mas tão somente apresentá-las.

\section{Uma sociologia sem sujeito: 0 anti-individualismo durkheimiano}

Muitos dos críticos de Durkheim salientam o caráter anti-individualista de sua sociologia. Alegam que ela constitui uma "artilharia pesada" contra a consciência individual, por um lado, contrapondo-se aos filósofos iluministas (Nisbet, 2003), por outro, dando forma a um tipo de sociologia "sem sujeito" (Dubet, 1996).

A maioria dessas críticas dirige-se a seus primeiros trabalhos em especial, Da Divisão do Trabalho Social; As Regras do Método Sociológico; e O Suicídio -, em que o sociólogo opõe-se, veementemente, tanto ao sujeito da psicologia quanto ao sujeito da filosofia. Isso porque, para ele, a sociedade não se reduz à soma de suas partes, constituindo uma realidade sui generis, detentora de uma consciência independente. Como afirmou em certa ocasião, "o conjunto de crenças e dos sentimentos comuns à média dos membros de uma mesma sociedade forma um sistema determinado, que tem vida própria; podemos chamá-lo de consciência coletiva" (Durkheim, 2008, p. 50, grifos do autor).

Disso decorre a superioridade da esfera social sobre a esfera individual. A sociedade, "produto de uma imensa cooperação que se estende não apenas no espaço, mas no tempo", apresenta-se como um ser psíquico distinto, cuja força se faz sentir sobre as consciências particulares. Trata-se, pois, do "mais poderoso feixe 
de forças físicas e morais", do qual se depreende uma vida mais elevada que reage sobre a "multidão de espíritos diversos" dos quais resulta, tornando-se, por isso, "uma intelectualidade mais rica e mais complexa que a do indivíduo" (Durkheim, 1989, p. 45).

Com efeito, devido à dinâmica de suas diversas instituições, a sociedade autonomiza-se em relação às suas unidades componenciais, investindo-se, assim, em uma autoridade moral que se afigura aos homens e da qual estes não podem se separar sob o risco de perder a melhor parte de si mesmos: a sua condição humana (Durkheim, 1978, p. 45).

Assim sendo, na ótica de seus críticos, Durkheim seria responsável por desenvolver uma espécie de "transcendentalismo" social. Georges Gurvitch (1986, p. 11), por exemplo, fala em uma identificação da "consciência coletiva" com o "imperativo, a razão a priori, o Bem Supremo e, finalmente, a Divindade", enquanto Theodoro Adorno (2008, p. 118) culpa o sociólogo francês por hipostasiar a sociedade, tornando-a uma "realidade de segundo grau". Desse ponto de vista, o indivíduo não passaria de um mero suporte das influências coletivas, ou seja, um ser passivo e impotente frente às forças exercidas pela realidade social.

Talvez por isso, a educação moral seja um dos temas mais recorrentes de sua sociologia, pois, em último caso, só é possível explicar o indivíduo a partir dos valores sociais, políticos, econômicos e culturais aos quais está submetido, que dependem da ação educativa para serem internalizados.

\section{Socialização, moralização e controle social}

Em seu itinerário intelectual, Durkheim dedicou grande parte de suas pesquisas a temas como socialização e moralidade. Estes, aliás, podem ser facilmente avistados em seus escritos sobre educação. Não é preciso ir muito longe. Em seu trabalho Educação e Sociologia, por exemplo, o autor analisa o modo como indivíduos, espacial e temporalmente situados, são socializados e passam a ocupar uma função social consoante a seu grupo originário. Mesmo consentindo que esse processo possa variar, visto que os valores diferem 
de uma sociedade para outra, salienta a imprescindibilidade da educação para a aculturação das novas gerações (Durkheim, 1978).

O sistema de ensino, que se tornou alvo de disputa na França, ${ }^{15}$ desponta no horizonte durkheimiano como o único capaz de formar o cidadão republicano dentro de um escopo racional e laico. Afinal, como a maior parte daqueles que passaram pela École Normale Supérieure, Durkheim nutria grande entusiasmo em relação ao republicanismo. Como transmitir os valores republicanos? Como forjar indivíduos afinados com os ideais da III República Francesa? (Ramos Torre, 1999).

A resposta às questões acima levantadas recai sobre o tipo de formação ofertada. Disso decorre a importância atribuída ao Estado - espécie de cérebro social - na organização do sistema de ensino. Na medida em que a educação é um "fato social", que cumpre uma dupla função (diferenciadora e homogeneizadora), então, não pode ficar à mercê dos interesses de grupos particulares, devendo, por isso, ser gerenciada por um órgão acima de quaisquer rivalidades, e de acordo com os ideais e os valores reclamados pela sociedade em seu conjunto.

Na visão dos críticos, porém, o processo pelo qual as gerações mais jovens são submetidas aos padrões sociais e culturais estabelecidos oculta um tipo de violência simbólica, sutil e eficaz (Wacquant, 2010). Trata-se da inculcação de valores e normas sociais por meio, sobretudo, do sistema escolar. Apesar das posições objetivistas assumidas em seus primeiros trabalhos, ao encarar a questão social como uma questão eminentemente moral, Durkheim desloca a discussão da esfera macroscópica, fonte autêntica da produção dos valores, para a esfera microscópica, implicando a deseconomização e a desistoricização das relações sociais. Os efeitos desse deslocamento reverberam na atribuição de uma dimensão psíquica aos

15 Na França, até o último quartel do século XVIII, o sistema de ensino esteve sob os auspícios da lgreja Católica. No decorrer do século XIX, entretanto, os republicanos liberais passam a reivindicar o seu domínio e a defender a sua laicização, o que desencadeou um longo e feroz embate entre os dois grupos. Com o advento da III República Francesa, em 1870, o projeto de educação republicano efetiva-se, a partir dos esforços de nomes como León Gambetta e Jules Ferry, ambos signatários do republicanismo liberal (Fernandes, 1994; Borrell, 2000). 
fatos sociais - evidenciada na distinção entre consciência coletiva e consciência individual -, situando, na esfera moral, qualquer tentativa de especificação do ser social.

A psicologização do social, assim como em Comte, não desemboca na individualização, mas na evidência societária das suas refrações mais fundamentais para o conservantismo: o problema da ordem. ${ }^{16}$ Em outras palavras, embora adote um viés bem menos especulativo do que o de seu predecessor, Durkheim, calcado sem dúvida em um quadro teórico mais sofisticado, conclui que um controle efetivo e operante depende da internalização de valores. $\mathrm{Na}$ medida em que focaliza, de um lado, certos mecanismos básicos que determinam a estratificação social e, de outro, as tensões que destes derivam, Durkheim toma a normatização como um instrumento de equalização dos conflitos sociais.

É nessa direção que se movem as críticas de Heloísa Fernandes (1994) e Maria Helena Oliva Augusto (2009). A educação, de modo geral, e a escola, em particular, promovem não apenas a socialização dos indivíduos, mas, sobremaneira, a sua moralização. O corolário disso é que as faixas mais jovens da população são vistas como moralmente incompletas, cabendo ao sistema de ensino o encargo de moralizá-las e adaptá-las à vida coletiva.

Segundo a interpretação desses críticos (Fernandes, 1994; Freitag, 1992; Augusto, 2009), o sociólogo francês toma a ação educativa como uma ação moralizante, na medida em que a função primacial da escola fica reduzida a introjetar na criança aqueles valores e aquelas normas requeridos pela sociedade. Desse ponto de vista claramente adultocêntrico, o indivíduo é compreendido como um ser da falta, da ausência, que necessita acessar o legado cultural produzido pelas gerações anteriores para poder desfrutar das benesses da vida social. A educação constituiria, assim, o principal mecanismo para a realização desta inserção. Todavia, subjacente ao processo de socialização-moralização, encontra-se a intenção

16 Essa crítica, aliás, é recorrente não só entre os marxistas, mas, também, entre autores funcionalistas, como Talcott Parsons (2010), e até mesmo entre os representantes do pensamento conservador contemporâneo, a exemplo de Robert Nisbet (2003). 
de moldar o indivíduo à ordem social. Visto que a própria divisão do trabalho desponta como empecilho a uma educação unitária, as diferenças entre os indivíduos justificariam-se pela necessidade que a sociedade tem de manter-se viva. Por isso, os desejos individuais necessitam ser limitados - em outros termos moralizados - para que cada um detenha-se à sua função sem o prejuízo do todo. Isso explica por que, segundo Fournier (2007), pode-se avistar em Durkheim uma intersecção entre educação, moralidade e organização da vida social. Ainda que alguns autores, a exemplo de Geneyro (1991), entendam que, para Durkheim, a educação corresponde a um dos pilares básicos para a formação do cidadão republicano, o papel socializador e moralizante que o sociólogo francês outorga ao sistema educacional levanta dúvidas sobre o caráter verdadeiramente democrático acerca de sua concepção de educação moral. ${ }^{17}$

\section{O naturalismo metodológico e a conservação da ordem social burguesa}

Entre as críticas mais comuns à sociologia durkheimiana, destaca-se a que advém do marxismo. Alguns autores identificados a essa corrente teórica, tais como Michael Löwy (2007) e José Paulo Netto (2011), entendem que Durkheim dá continuidade ao positivismo de Comte, não obstante adote uma postura menos mística e mais científica. Para esses intérpretes, o modo como o sociólogo francês encara os fenômenos sociais, tomando-os como fatos similares aos naturais, pois são supostamente submetidos às mesmas leis, configuraria uma espécie de "conservadorismo metodológico".

17 Sobre a intersecção entre educação, autoridade e moralidade, recomenda-se o excelente artigo de Juan Pablo Vázquez Gutiérrez (2002). Nele, o comentador procura demonstrar que a concepção de educação sustentada por Durkheim só pode ser devidamente compreendida à luz da teoria moral, já que, no que se refere à moral das sociedades modernas, o "espírito de autonomia" desponta como um novo elemento, ausente, nesse sentido, na moral típica das sociedades tradicionais. Outro texto determinante para se compreender melhor a moral concebida por Durkheim para a sociedade moderna é o de Hans Joas (2012). Aqui, encontra-se não só uma análise bastante pormenorizada do caráter distintivo da moralidade moderna, mas, também, de seus impactos para a expansão das liberdades individuais. Por último, indicamos o artigo de Raquel Weiss (2009), no qual a autora procura demonstrar que é na concepção de educação que reside a chave para a compreensão da passagem do positivo para o normativo em Durkheim. 
De fato, sobretudo em suas primeiras obras, Durkheim adota um escopo francamente organicista, segundo o qual a sociedade caracteriza-se como um "organismo vivo", formado por partes interdependentes e em uma correlação hierárquica que, para funcionar bem, necessitam de um ordenamento mínimo. Não por acaso, o princípio metodológico fundamental de sua sociologia considera os fatos sociais como "coisas". Essa ideia, exposta primeiramente pelos representantes da econômica política e, mais tarde, absorvida pela filosofia social comteana, serve bem às pretensões do sociólogo, que estabelece as bases de seu método "naturalista-positivista".

$\mathrm{Na}$ ótica dos críticos marxistas, Durkheim foi responsável por subverter o caráter revolucionário das doutrinas naturalistas que, nas mãos dos insurretos de 1789, serviram para destruir a ordem social aristocrática. O sociólogo é acusado de empregá-las como justificação científica da ordem social burguesa, visto que, para ele, as leis naturais da sociedade impõem-se à vontade humana e não podem ser abruptamente modificadas. Destarte, sua sociologia estaria na contramão do pensamento utópico e revolucionário, negando, por conseguinte, toda ação transformadora. Na medida em que a sociedade, como qualquer outro organismo, possui uma dinâmica própria, independentemente das volições particulares, qualquer ação no sentido de interromper, interferir ou transformar as suas leis põe em risco o curso natural da vida social. Desse ponto de vista, as diferenças resultantes da divisão do trabalho podem ser consideradas naturais, já que alguns órgãos sociais, por suas especificidades funcionais, gozam de uma situação especial e mesmo privilegiada em relação a outros órgãos. Trata-se, pois, da naturalização das desigualdades sociais, já que, a exemplo do que acontece na natureza, cada grupo social não reclama senão a quantidade proporcional à sua necessidade. Com efeito, as ideias revolucionárias soam a Durkheim como "sonhos infantis", meras projeções, ainda que revestidas de um discurso científico.

A démarche durkheimiana apoia-se em um pressuposto basilar, a saber: a homogeneidade epistemológica dos distintos domínios científicos. Não sem propósito, Durkheim exige do sociólogo uma 
postura objetiva, tal como o químico ou o biólogo, ao se debruçarem sobre os seus respectivos objetos. Entretanto, questionam os críticos marxistas: como o cientista social pode se colocar no mesmo estado de espírito desses outros cientistas, se o objeto de seu estudo, a sociedade, constitui um terreno marcado por diferentes concepções de mundo e interesses sociais radicalmente opostos? Como ignorar o combate político-ideológico travado no campo social? É possível falar em neutralidade analítica em ciências sociais?

Para os referidos críticos, o princípio exposto pelo autor de $A s$ Regras do Método Sociológico, segundo o qual o sociólogo deve "afastar sistematicamente as prenoções", bem como "cercar-se de todas as precauções possíveis contra as influências irracionais", é inócuo em termos científicos. Em resumo, os marxistas refutam a noção de objetividade analítica, difusa entre os positivistas, bem como salientam a ingenuidade da análise durkheimiana, centrada em uma acepção naturalista, organicista e evolucionária de sociedade, elementos que, em última instância, contribuem para a legitimação da ordem social burguesa e reforçam o rótulo de "conservador" que recai sobre sua sociologia.

\section{Durkheim e o conservadorismo: à guisa de conclusão}

Observemos, a seguir, o que afirma Robert Nisbet sobre a sociologia durkheimiana e a tradição conservadora que a precede:

no começo do século XIX os conservadores constituíram uma força anti-iluminista. Na realidade não há uma só palavra, uma só ideia central daquele renascimento conservador, que não procure refutar as ideias dos philosophes. [...] No final do século, nas obras de Durkheim, de ideias não religiosas e liberais em política, encontramos certas teses do conservadorismo francês convertidas em algumas das teorias essenciais de sua sociologia sistemática: a consciência coletiva, o caráter funcional das instituições e ideias, as associações intermediárias e também seu ataque ao individualismo (Nisbet, 2003, p. 26-27, tradução nossa). 
Seria Durkheim um conservador? Se, caso a resposta for positiva, a que tipo de conservadorismo o sociólogo francês estaria vinculado? Tratar-se-ia de um conservadorismo reacionário, tradicionalista ou liberal? Poderíamos considerar a sua sociologia como sendo absolutamente conservadora?

Tais indagações, postas no início deste artigo e reiteradas agora, revelam-se de suma importância, pois trazem à tona uma série de nuances que podem amenizar ou acentuar as posições assumidas pelo sociólogo ao longo de sua carreira. Uma resposta conclusiva, todavia, depende de uma análise minuciosa das críticas que lhe foram endereçadas. Do contrário, o rótulo de conservador tende a tomar a forma mais dilatada possível, colocando Durkheim no mesmo patamar de autores que, a nosso ver, distanciam-se, tanto programática quanto metodologicamente, de suas propostas mais fulcrais. Desse modo, nesta última seção, pretende-se percorrer as críticas anteriormente anunciadas e, a partir de uma análise minuciosa, posicionarmo-nos em relação ao sentido mais original de sua sociologia.

Aliás, entre as inúmeras críticas dirigidas a Durkheim, uma merece especial atenção: a que aponta o caráter anti-individualista de sua sociologia. Os sociólogos Robert Nisbet (2003) e François Dubet (1996) são um exemplo disso. Ambos identificam uma oposição radical entre as posições durkheimianas e aquelas assumidas pelos filósofos iluministas. Mas, em que medida Durkheim é um anti-individualista? Até que ponto a sua sociologia contrapõe-se ao legado iluminista?

Anthony Giddens (1998), um dos maiores estudiosos de Durkheim, lança algumas luzes sobre o assunto. Em um artigo intitulado Durkheim e a Questão do Individualismo, o sociólogo britânico ajuda a desvelar o lugar que o indivíduo ocupa na sociologia durkheimiana. Conforme argumenta, os escritos de Durkheim representam uma tentativa de separar o individualismo liberal - encarado como uma das características fundamentais da ordem social moderna - tanto do individualismo metodológico dos utilitaristas quanto do individualismo ético de Kant. Sendo assim, 
para que as posições utilitaristas e kantianas pudessem ser rejeitadas, o individualismo teria que se referir a um processo social, visto que a sociologia não podia basear-se em uma teoria cujo ponto de partida é o indivíduo. Se o sociólogo francês admite que a "consciência coletiva" impõe-se tiranicamente aos indivíduos, sufocando-os, também salienta, no tocante às sociedades funcionalmente complexas, que esta tende a enfraquecer, estimulando o individualismo. Uma forte consciência moral só adquire sentido em relação às sociedades tradicionais, mas nunca em relação às sociedades modernas, dada complexidade que se lhe encerram. Por esse prisma, o individualismo desponta não como um efeito deletério, mas como uma das características definidoras do mundo moderno. A discussão em torno do "individualismo moral", iniciada em $\mathrm{Da}$ Divisão do Trabalho Social e substancialmente esclarecida em seus escritos posteriores, sobretudo após a apreciação subsequente das íntimas conexões entre religião e autoridade moral, abre espaço para demonstrar que a expansão das liberdades individuais constitui um imperativo histórico-social inadiável e necessário - que nada tem a ver com a perseguição dos interesses próprios. Destarte, em termos substantivos, fica evidenciado que Durkheim, longe de ignorar o legado iluminista, esforça-se para concretizar os ideais da Revolução Francesa, ${ }^{18}$ embora, em termos metodológicos, o seu afastamento da interpretação segundo a qual o indivíduo é o ponto de partida da explicação e da transformação social, propagada pelos philosophes, seja mais do que esperado, dado que, para ele, a própria individuação resulta de um longo e lento processo coletivo.

Já a acusação de que Durkheim, por meio de sua sociologia moral e da educação, defende a moralização das novas gerações, forjando-as no sentido de adequá-las aos valores e à estrutura social vigente, parece desconsiderar o fato de que, independentemente do tempo e do espaço, qualquer sociedade procede desse modo. Em outras palavras, não há meio social em que as gerações adultas não ajam sobre as gerações mais jovens por meio das diversas instâncias

18 Referimo-nos aos ideais contidos na Declaração dos Direitos do Homem, de 1793. 
socializadoras. A favor do autor, pode-se afirmar que este jamais coadunou com a ideia de uma estagnação moral via reprodução geracional. $\mathrm{O}$ modo como opôs o individualismo moral às formas tradicionais de moralidade constitui uma clara prova disso.

Finalmente, a crítica marxista segundo a qual a sociologia durkheimiana constitui uma defesa da ordem burguesa é a mais difícil de ser combatida. Isso porque o naturalismo empregado pelo sociólogo francês deixa pouco espaço para se pensar nas relações de poder entre as diversas frações sociais que configuram a complexa sociedade industrial moderna. De fato, Durkheim está longe de ser um crítico do modelo liberal, entendido como resultado de um longo processo histórico-social. Mas, ainda assim, é possível fazer algumas ponderações.

Em primeiro lugar, Durkheim repudia totalmente a lógica da dominação classista. O sociólogo jamais atribuiu qualquer vantagem a um estrato social específico - tal como Saint-Simon e sua "classe de industriais". Parece desnecessário discutir a visão de Durkheim sobre a sociedade capitalista. Para ele, a ordem social industrial constitui uma etapa importante da evolução histórica. Mas disso não decorre que coadune com a exploração gerada em seu interior. Em diversas ocasiões, aliás, o autor aponta soluções no sentido de equalizar as desigualdades sociais: a extinção da herança, o fortalecimento das corporações profissionais, eleições baseadas em um amplo sistema de corporações nacionais, em vez das velhas organizações distritais, um Estado fiscalizador, comprometido com a sociedade civil em seu conjunto e, o mais importante, a consolidação de uma moral laica e racional, capaz de limitar os insaciáveis apetites humanos, independentemente de classe social.

Em segundo lugar, a crítica marxista tende a ignorar as diferenças programáticas, metodológicas e substantivas que marcam os trabalhos dos autores vinculados ao positivismo. Assim, Durkheim é visto como mero decalque de Comte, um seguidor dos apologistas católicos conservadores e, por suposto, um conservador. O grande problema dessa interpretação é que não há maiores preocupações em desvelar as características intrínsecas a cada um desses sistemas 
sociológicos, nem o contexto específico em que tiveram origem. Ao fim e ao cabo, dentro de um escopo marxista, os sociólogos positivistas equivalem-se, à medida que representam os valores burgueses.

É bem verdade que Durkheim, a exemplo dos conservadores clássicos, jamais abandonou a perspectiva evolucionária da história, segundo a qual uma intervenção abrupta ou revolucionária põe em risco a sua dinâmica. Mas, não obstante essa aproximação, o sociólogo rejeitou o reacionarismo imbricado na defesa da transposição de valores passadistas, típicos das sociedades tradicionais, para as sociedades complexas - como no caso de Comte -, ou mesmo a ideia de um retorno às sociedades tradicionais - conforme defendiam Maistre, Bonald e Chateaubriand. Ademais, seu evolucionismo histórico nada tem de teleológico, no sentido de indicar uma superioridade - seja ética, seja ontológica, seja política - das sociedades industriais em relação a outras formas mais simples de organização social. Afinal, o critério empregado pelo autor para discernir as sociedades complexas das tradicionais é meramente morfológico, baseado na divisão do trabalho. Trata-se, pois, de modelos sociais distintos, cada qual com seus valores específicos, mas que não podem e nem devem ser analisados em termos de superioridade/inferioridade ou em termos finalísticos.

Talvez agora possamos responder às questões levantadas ao longo deste trabalho. É correto afirmar que Durkheim flertou com o pensamento conservador, sobretudo no início de sua carreira. $\mathrm{O}$ próprio sociólogo jamais omitiu tal influência. Contudo, se um pensador inclina-se no sentido de uma determinada fonte intelectual, isso não significa que reproduzirá integralmente as ideias por ela compreendidas. Em outros termos, o fato de Durkheim lançar mão de noções extraídas da filosofia social conservadora não faz dele, automaticamente, um conservador. Para melhor explicitar nossa posição, vale a pena sublinhar alguns pontos. 
Primeiro ponto: o conservadorismo não constituiu a única fonte teórica com a qual Durkheim relacionou-se. Como tivemos oportunidade de verificar, as fontes durkheimianas são bem mais amplas e transcendem os limites do pensamento conservador. Isso reforça a posição assumida por Peter Burke a respeito dos modelos explicativos utilizados na análise dos processos sociais. Definidos como uma "construção intelectual que simplifica a realidade com o objetivo de entendê-la", estes modelos constituem uma espécie de mapa, cuja "utilidade depende da completa omissão de alguns elementos dessa mesma realidade" (Burke, 2002, p. 45). Ora, um olhar mais atento sobre os grandes sistemas sociológicos que marcaram a passagem do século XIX para o século XX é o suficiente para verificar que não há, entre os grandes sociólogos desse período, uma única figura significativa cujas ideias não envolvam algum tipo de síntese das diversas correntes ideológicas - conservadorismo, liberalismo, solidarismo e socialismo. Durkheim, certamente, não é uma exceção.

Segundo ponto: a influência da filosofia moral kantiana é tão ou mais significativa do que a presença do positivismo comtiano. Se os primeiros trabalhos de Durkheim encarnam o cientificismo típico da filosofia positivista, os trabalhos ulteriores estão muito mais sintonizados com os problemas kantianos, o que, inclusive, contribuiu para o direcionamento de seus estudos, que passaram a se preocupar com temas como o sagrado e a religiosidade.

Terceiro ponto: a maior parte daqueles que apontam o caráter conservador da sociologia durkheimiana ignora a sua dimensão histórica, ou seja, desconsidera a passagem da solidariedade mecânica para a solidariedade orgânica - apresentada em sua tese doutoral - como a base fundamental de sua análise sociológica. $\mathrm{O}$ resultado disso é que há uma tendência em tomar os elementos morais e funcionais típicos da ordem social tradicional como sendo os elementos definidores da ordem social moderna.

Quarto ponto: do fato de não creditar às revoluções (rupturas descontínuas) um papel histórico crucial não decorre que Durkheim ignore as transformações, muito pelo contrário. Conforme expôs 
em diversas ocasiões, toda e qualquer mudança no interior de um sistema social integrado configura um processo gradual e coletivamente construído, de tal modo que só uma ação coletiva tem força suficiente para modificar uma convenção, já que o indivíduo isolado pouco ou nada pode contra uma norma ou tradição instituída. Sua teoria, portanto, está longe de ser homeostática como comumente se afirma.

Quinto ponto: o lugar central ocupado pelo indivíduo na moralidade atinente às sociedades funcionalmente complexas sinaliza que, apesar das críticas empreendidas ao utilitarismo, Durkheim reconhece a individualidade como um valor necessário ao mundo moderno. Isso, sem dúvida, reforça a observação anterior de que a sua sociologia configura um desejo de sintetizar conservadorismo e liberalismo, sem recorrer às soluções radicais incutidas no socialismo.

Sexto e último ponto: o ponto de partida das inflexões durkheimianas não é o problema da ordem, no sentido hobbesiano conforme assinala Parsons -, e sim o tipo de moralidade mais adequado às sociedades industriais modernas. Longe de querer elaborar novas formas de controle social, as preocupações de Durkheim orbitam em torno da necessidade de um conjunto de valores que dê conta de atender às demandas de uma sociedade cada vez mais centrada na expansão das liberdades individuais.

Com efeito, a alcunha "conservador" tende a minimizar toda a complexidade que encerra a sociologia durkheimiana. Como outros grandes pensadores sociais daquela época, Durkheim procurou articular as diversas tendências de pensamento circulantes na Europa. Tomá-lo como um conservador, no sentido mais estrito do termo, significa desconsiderar a multiplicidade de influências que contribuiu para a edificação de sua teoria sociológica. Destarte, não obstante o reconhecimento da influência parcial exercida pela filosofia conservadora, sua sociologia tem um débito, senão maior, pelo menos igual, com outras correntes, o que nos impede - por uma questão de cautela - de designarmos o conjunto de seus trabalhos como sendo exclusivamente conservador. No máximo, talvez 
possamos auferir-lhe o rótulo de liberal em termos políticos, metodologicamente socializante e conservador, com a ressalva, porém, de que se trata de um recorte arbitrário, com finalidades puramente didáticas, pois, para além de quaisquer rubricas, uma obra tão vasta e complexa como a de Durkheim, similarmente às obras não menos abrangentes de Marx e Weber, não pode ser reduzida a uma única vertente de pensamento sem gerar as distorções analíticas e interpretativas usuais.

\section{Referências}

ADORNO, Theodoro. Introdução à sociologia. Tradução de Wolfgang Leo Maar. São Paulo: Unesp, 2008.

AUGUSTO, Maria Helena Oliva. Indivíduo e moral em Durkheim. In: MASSELLA, Alexandre et al. (Orgs.). Durkheim: 150 anos. Belo Horizonte: Argvmentvm, 2009. p. 209-230.

BORRELL, Joan. Ferry, Durkheim, idêntica lucha. Nacimiento de dos hermanos gemelos: el sociólogo y el maestro de escuela. In: DURKHEIM, Émile. Educación y sociologia. 2. ed. Barcelona: Península, 2000. p. 137-188.

BURKE, Peter. História e teoria social. Tradução de Klauss Brandini Gerhardt e Roneide Venâncio Majer. São Paulo: Unesp, 2002.

COUTINHO, João Pereira. As ideias conservadoras: explicadas a revolucionários e reacionários. São Paulo: Três Estrelas, 2014.

DOMINGUES, Ivan. Epistemologia das ciências humanas. São Paulo: Loyola, 2004.

DUBET, François. Sociologia da experiência. Lisboa: Instituto Piaget, 1996.

DURKHEIM, Émile. Educação e sociologia. 7. ed. Tradução de Lourenço Filho. São Paulo: Melhoramentos, 1978. 
. Da divisão do trabalho social. 3. ed. Tradução de Eduardo Brandão. São Paulo: Martins Fontes, 2008.

ESCORSIM NETTO, Leila. O conservadorismo clássico: elementos de caracterização e crítica. São Paulo: Cortez, 2011.

FERNANDES, Florestan. Fundamentos empíricos da explicação sociológica. 4. ed. São Paulo: T. A. Queiroz, 1980.

FERNANDES, Heloísa Rodrigues. Sintoma social dominante e moralização infantil: um estudo sobre a educação moral em Émile Durkheim. São Paulo: Edusp; Esculta, 1994.

FOURNIER, Marcel. Émile Durkheim. Paris: Fayard, 2007.

FREITAG, Bárbara. Itinerários de Antígona: a questão da moralidade. Campinas: Papirus, 1992.

GENEYRO, Juan Carlos. La democracia inquieta: E. Durkheim y J. Dewey. Madrid: Anthropos, 1991.

GIDDENS, Anthony. Durkheim e a questão do individualismo. In: GIDDENS, Anthony. Política, sociologia e teoria social: encontros com o pensamento social clássico e contemporâneo. Tradução de Cibele Saliba Rizek. São Paulo: Unesp, 1998. p. 147-168.

. Em defesa da sociologia: ensaios, interpretações e tréplicas. Tradução de Roneide Venâncio Majer e Klauss Brandini Gerhardt. São Paulo: Unesp, 2001.

. Capitalismo e moderna teoria social. 6. ed. Tradução de Maria do Carmo Cury. Lisboa: Presença, 2005.

GIROLA, Lidia. Anomia e individualism: del diagnóstico de la modernidad de Durkheim al pensamiento contemporáneo. Barcelona: Anthropos, 2005.

GURVITCH, Georges. Vocação actual da sociologia. Tradução de Orlando Daniel. Lisboa: Cosmos, 1986. v. 2 
GUTIÉRREZ, Juan Pablo Vázquez. Autoridad moral y sociedad en el pensamiento de Durkheim. Sociologica, v. 17, n. 50, p. 17-54, 2002.

HUNTINGTON, Samuel. Conservatism as an ideology. The American Political Science Review, v. 51, n. 2, p. 454-473, 1957.

JOAS, Hans. A sacralidade da pessoa: nova genealogia dos direitos humanos. Tradução de Nélio Schneider. São Paulo: Editora Unesp, 2012.

KINZO, Maria D’Alva Gil. Burke: a continuidade contra a ruptura. In: WEFFORT, Francisco. Os clássicos da política. 11. ed. São Paulo: Ática, 2006. p. 15-45, v. 2.

KIRK, Russell. A política da prudência. Tradução de Gustavo Santos e Márcia Xavier de Brito. São Paulo: É Realizações, 2013.

LÖWY, Michael. Ideologias e ciência social: elementos para uma análise marxista. 17. ed. São Paulo: Cortez, 2006.

- As aventuras de Karl Marx contra o Barão de Münchhausen: marxismo e positivismo na sociologia do conhecimento. 9. ed. Tradução de Juarez Guimarães e Suzanne Felicie Léwy. São Paulo: Cortez, 2007.

LUKES, Steven. Émile Durkheim su vida y su obra: estúdio históricocrítico. Madrid: Siglo XXI, 1984.

NETTO, José Paulo. Capitalismo monopolista e serviço social. 8. ed. São Paulo: Cortez, 2011.

NISBET, Robert. La formacion del pensamiento sociológico, v. 1-2. Buenos Aires: Amorrortu, 2003.

PARSONS. Talcott. A estrutura da ação social. Tradução de Vera Joscelyne. Petrópolis: Vozes, 2010. v. 1. 
RAMOS TORRE, Ramón. La sociologia de Émile Durkheim: patología social, tiempo, religión. Madrid: Centro de Investigaciones Sociológicas, 1999.

TIRYAKIAN, Edward. Émile Durkheim. In: NISBET, Robert; Bottomore, Tom (Orgs.). História da análise sociológica. Tradução de Waltersin Dutra. Rio de Janeiro: Zahar, 1980. p. 252-316.

VICENTE, Andrew. Ideologias políticas modernas. Tradução de Ana Luiza Borges. Rio de Janeiro: Zahar, 1995.

WACQUANT, Loïc. Durkheim e Bourdieu: a base comum e suas fissuras. [S.l.]: [s.n.], 2010. On-line. Disponível em: <http://www. lcqribeiro.pro.br>. Acesso em: 7 abr. 2016.

WEISS, Raquel. A concepção de educação de Durkheim como chave para a passagem entre o positivo e o normativo. In: MASSELLA, Alexandre et al. (Orgs.). Durkheim: 150 anos. Belo Horizonte: Argvmentvm, 2009. p. 169-189.

ZEITLIN, Irving. Ideología y teoria sociológica. Buenos Aires: Amorrortu, 1973.

DURKHEIM, Émile. O individualismo e os intelectuais. In: DURKHEIM, Émile. A ciência social e a ação. Tradução de Inês Duarte Ferreira. São Paulo: Difel, 1975. p. 235-250. . As formas elementares da vida religiosa. Tradução de Joaquim Pereira Neto. 2. ed. São Paulo: Paulus, 1989.

. Educación y sociologia. 2. ed. Barcelona: Península, 2000. . Lições de sociologia. Tradução de Mônica Stahel. São Paulo: Martins Fontes, 2002.

- Ética e sociologia moral. Tradução de Paulo Castanheira. São Paulo: Landy, 2003. 
. As regras do método sociológico. 3. ed. Tradução de Paulo

Neves. São Paulo: Martin Fontes, 2007.

NISBET, Robert. Conservantismo. In: NISBET, Robert; Bottomore,

Tom (Orgs.). História da análise sociológica. Tradução de Waltersin Dutra. Rio de Janeiro: Zahar, 1980. p. 118-165. . Conservadurismo. Madrid: Alianza Editorial, 1995.

ORTIZ, Renato. Durkheim: um percurso sociológico. In: ORTIZ, Renato. Ciências sociais e trabalho intelectual. São Paulo: Olho D’Água, 2002. p. 123-148.

RICHTER, Melvin. Durkheim's Politics and Political Theory. In:

DURKHEIM, Émile et al. Essays on sociology and philosophy. London: Harper, 1964. p. 17-49.

\section{Resumo}

Este artigo propõe-se a discutir a relação entre a teoria sociológica desenvolvida por Émile Durkheim e as ideias conservadoras clássicas. Por um lado, visa-se compreender em que medida o sociólogo francês absorveu elementos conservadores em sua sociologia e, por outro, se essa suposta influência bastaria para atribuir à obra durkheimiana uma rubrica conservadora. Com isso, pretende-se evitar possíveis rótulos ou tipificações, quase sempre reducionistas e incapazes de dar conta de toda a complexidade que envolve uma produção teórica de grande fôlego, como a de Durkheim. A análise empregada é eminentemente bibliográfica e revisionista, assentando-se tanto em fontes primárias quanto em fontes secundárias.

Palavras-chave: conservadorismo; liberalismo; sociologia; moral; metodologia. 


\section{Abstract}

This article proposes to discuss the relationship between the sociological theory, developed by Emile Durkheim and the classic conservative ideas. On the one hand, it seeks to understand to what extent the French sociologist absorbed conservative elements in his sociology and, on the other hand, if this supposed influence would suffice to attribute to the Durkheimian work a conservative rubric. With this, it is intended to prevent possible labels or typifications, almost always reductionist and unable to realize all the complexity that involves a theoretical production of great value like the work of Durkheim. The analysis is mostly bibliographic and revisionist and builds both on primary and secondary sources.

Keywords: conservatism; liberalism; sociology; moral; methodology.

Recebido em 29 de novembro de 2014. Aprovado em 19 de setembro de 2015. 